\title{
ZA I PROTIV OTVORENOG PRISTUPA AKADEMSKIM DJELIMA U KONTEKSTU SAVREMENOG ISTRAŽIVAČKO-IZDAVAČKOG PROCESA
}

\author{
Prof. dr. Srebren Dizdar \\ Filozofski fakultet Univerziteta u Sarajevu Sarajevo, Bosna i Hercegovina \\ Faculty of Philosophy, University of Sarajevo, Sarajevo, Bosnia and Herzegovina \\ srebren.dizdar@ff.unsa.ba
}

\begin{abstract}
Sažetak
Od vremena ubrzanog uvođenja informacijskih tehnologija i internetskih servisa na djelu su inicijative da se, po određenim uslovima, sva objavljena, štampana i digitalizirana, djela učine dostupnim svim ljudima, a naročito onima koji pripadaju istraživačko-akademskoj zajednici. Princip ili politika otvorenog pristupa (Open Access Policy) u ovih dvadesetak godina stekao je brojne zagovornike, ali i određen broj protivnika, koji razložno ukazuju na opasnosti zloupotreba od tzv. grabežljivih akademskih izdavača i svekoliku komercijalizaciju u nedovoljno jasno usaglašenim pravno obavezujućim dokumentima na međunarodnom i lokalnom planu o ovoj problematici. U radu se daje kraći historijski pregled razvoja akademskog izdavaštva od 17. do kraja 20. stoljeća te znatno promijenjenog okruženja u kojem se pokušavaju prevazići brojne pravne i druge nedoumice vezane za istraživački rad i s njim povezane aktivnosti u oblasti savremenog izdavaštva. $U$ okviru tog dinamičnog procesa događaju se brojne promjene u pristupu i vrednovanju svih oblika akademskog pisanja, redefiniraju se pitanja autorskih i izdavačkih prava te navode oblici i modaliteti (samo)pohranjivanja i objavljivanja zaključenih publikacija i njihove potonje diseminacije zainteresiranim korisnicima bez ograničenja. Iznose se i prednosti koje omogućava otvoreni pristup, ali i ukazuje na određene negativnosti s kojima će se morati suočavati ove aktivnosti u budućnosti, sve dok se ne postigne saglasnost na globalnom planu o standardima koji će tokom 21. stoljeća u potpunosti regulirati ovu oblast.
\end{abstract}

Ključne riječi: otvoreni pristup, zagovornici i protivnici, autorstvo, oblici pohranjivanja, publikacije, diseminacije i korištenja akademsko-naučnih djela bez ograničenja, budućnost akademskog izdavaštva u digitalnom okruženju 21. stoljeća

\section{Uvod}

Koliko puta ste se susreli sa situacijom kada ste htjeli da dođete do informacije u okviru nekog elektronskog repozitorija, pa ste bili upitani da na ekranu kompjutera upišete kombinaciju slova i brojeva kako biste dokazali da niste robot nego ljudsko biće ("are you a robot, or a human being?"). Na ekranu se obično pojavi kôd CAPTCHA (Completely Automated Public Turing test to Tell Computers and Humans Apart = potpuno automatizirani javni test koji razdvaja računare i ljudska bića), a koji računarski programi (bar zasad!) ne mogu riješiti, nego je potrebna, doslovno, ljudska ruka da pritisne odgovarajuću funkciju kako bi se korisniku omogućio pristup podacima u programu ili bazi podataka koju želi posjetiti. U ovom slučaju se čini da je ljudsko biće naizgled moćnije od mašine, baš kao što ljudi odvajkada žele da spoznaju kako onaj vanjski svijet u kojem obitavaju kao prirodna bića zajedno sa drugim biljnim i životinjskim vrstama na planeti Zemlji, tako, još i više, svoju nutrinu, onu svoju često nedokučivu psihosomatsku i/li (raz)umnu stranu. Ta radoznala strana je nagnala ljude da otkrivajući i razaznavajući svijet oko sebe sve više nastoje i da ga objasne, što je, opet, kad bi se došlo do pouzdanih odgovora, pokretalo nova pitanja i potragu za novim objašnjenjima. U toj neobično dinamičnoj interakciji sa prirodom i sâmim sobom širio se krug saznanja, a time i spoznaje, količine, ali i kvaliteta znanja što su se prenosili sa generacije na generaciju ne samo kao stečeno iskustvo nego i kao dobra osnova za nova otkrića.

Neki od tih blistavih trenutaka iz historije ljudskog roda danas se pamte skoro na razini anegdote, kao što se uči u školi, kada je antički mislilac Arhimedes iz Sirakuze na otoku Siciliji (A $\propto \chi \mu \eta ́ \delta \eta$ s, oko 287. oko 212. pr. n. e.) izletio gol-golcat iz javnog kupa-

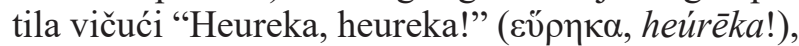
odnosno: "Otkrio sam!" Manje je poznato da je 
prethodno dobio zadatak da utvrdi da li je kruna koju je lokalni zlatar napravio za kralja Hiera II, okrutnog vladara grčke kolonije u Sirakuzi, doista napravljena od čistog zlata, ili je, možda, u njoj bilo i nekog manje vrijednog metala, tačnije srebra. Budući da nije smio oštetiti dragocjeni simbol tiranske vlasti, znameniti filozof je do rješenja došao gotovo slučajno. Naime, posmatrao je kako se podiže voda $\mathrm{u}$ istoj zapremini koliko iznosi tijelo koje se u nju uroni, pa je zaključio da mu to može pomoći da izračuna gustoću upotrijebljenog materijala, a da pri tom ne mora taliti krunu i na taj način odrediti da li je u njoj samo zlato ili još nešto. Danas se u akademskim krugovima koristi izraz "heuristika"

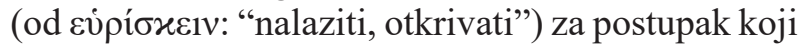
vodi otkriću, ili ga barem podstiče. Taj postupak je jedna od ključnih faza ka dosezanju narednih saznanja kao pretpostavke cjelovitije spoznaje u smislu novog kvaliteta otkrivenih znanja u odnosu na one koje su dotad postojale, ili se bar za njih znalo.

Pominjanje Arhimedesa nije bilo slučajno. Ono ukazuje na činjenicu da su misleći ljudi jako dugo, doslovno hiljadama godina, dolazili samostalno do tih otkrića, kao izuzetno nadareni pojedinci, koje je vodila svojevrsna sklonost, strast, ljubav ka znanju i mudrosti. Odatle, uostalom, i potiče riječ "filozof" pı Pretpostavlja se da ga je skovao Pitagoras sa otoka Samosa (oko 570. - oko 495. pr. n. e.), kojem dugujemo mnoga otkrića iz matematike (Pitagorin poučak!), ali i fizike, astronomije, klimatologije, pa i psihologije, numerologije i raznih mističnih učenja. Nije posve jasno da li je doista on zaslužan za sva otkrića koja mu se pripisuju, ali upravo je ta izoliranost, zatvorenost u vlastiti um i znanja koja se u njima kriju umnogome uticala na relativno spori napredak naučne misli uopće. Dostupna znanja su se teško širila izvan šačice učenika antičkih grčkih i rimskih filozofskih škola, potom srednjovjekovnih samostana, ili islamskih učenjaka koji su prenosili sadržinu svojih blistavih umova tek nekolicini posvećenih što su se, zajedno sa svojim učiteljima i nekolicinom drugih učenika, odlučivali na to neizvjesno putovanje. Zasigurno je tome doprinijela i nemogućnost da se ta saznanja učine dostupnim većem broju pismenih ljudi sve do pronalaska Gutenbergove prese sredinom 15. stoljeća i potonjeg naglog širenja pismenosti u zapadnoj Evropi. U širenju akademske pismenosti na novi način su značajnu ulogu odigrale i posve nove odštampane publikacije sa kojima, doista, i počinje nezadrživi razvoj kako same nauke, tako i akademskog izdavaštva uopće. Iako su još u starom Rimu postojale neke vrste "novina" u kojima su se iznosili pojedini važni događaji, ili se radilo o važnim javnim ličnostima tog vremena, sve do druge polovine 17. stoljeća nisu zabilježeni sređeni kritički zapisi um- jetničkog i intelektualnog stvaralaštva, koji bi mogli biti dostupni većem broju zainteresiranih čitalaca. Nesumnjivo je tome doprinijelo i mukotrpno prepisivanje rukopisa u srednjovjekovnim skriptorijima, koje je bilo izuzetno sporo i ograničeno na neveliki broj primjeraka, uglavnom vjerske prirode, te su kritički spisi kolali, uglavnom, u rukopisima u, opet, uskom krugu zainteresiranih mislećih ljudi. Ponešto je paradoksalno da se značajnija akademska produkcija nije razvila za vrijeme sjajnog perioda renesanse u Evropi, a da je prošlo 220 godina od štampanja prvih knjiga novom tehnikom Gutenbergove prese prije nego su se u okviru kraljevskih društava najučenijih ljudi tog vremena počeli sabirati i objavljivati radovi sa pretežno znanstveno-akademskom sadržinom.

\section{Pojava prvih naučnih časopisa}

Treba se sjetiti da je prije više od 350 godina izašao prvi naučni časopis Journal des scavants (Časopis mislećih ljudi) u Francuskoj, a i Philosophical Transactions of the Royal Society (Filozofska razmatranja Kraljevskog društva) u Engleskoj je objavljen iste, 1665. godine. Bile su to prve specijalizirane periodične publikacije čija je sadržina gotovo u cijelosti bila posvećena istraživanju i nauci uopće. Broj akademskih ili naučnih/znanstvenih časopisa i drugih serijskih publikacija u međuvremenu je narastao do ogromnog broja. Samo u 18. stoljeću pojavilo se preko hiljadu takvih publikacija, uglavnom, u početku, kao dnevnih izdanja, ali su ona nekako uspijevala da nastave kao časopisi, obično kao tromjesečnici (quarterlies), ili na nekoj drugoj redovnoj vremenskoj osnovi. S uvođenjem koncepta von Humboldtovog tipa univerziteta u Berlinu na početku 19. stoljeća kao kombinacije nastavne/obrazovne i istraživačke institucije, potreba za naučnim časopisima je shvaćena ne samo kao željena i prestižna nego, u neku ruku, i kao obavezna aktivnost.

Objavljeni rezultati nečijeg istraživanja postali su ne samo pitanje akademskog prestiža nego i indikator kvaliteta u nekoj znanstvenoj disciplini ili oblasti. To je uticalo na to da na državnim univerzitetima u Evropi, ili na privatnim univerzitetima u SAD, skoro pa doslovno procvjeta akademsko izdavaštvo, bilo u formi specijaliziranih univerzitetskih izdavačkih kuća (university presses) ili akademskih časopisa, te da se taj dinamični trend nastavi sve do kraja posljednje četvrtine 20. stoljeća, kada smo svjedočili "zlatnom dobu" raznovrsnih i izuzetno brojnih znanstvenih časopisa iz svih tada poznatih disciplina. U tome nije zaostajala ni Bosna i Hercegovina, koja je potkraj 1980-ih dosegla zavidnu razinu od preko 300 periodičnih publikacija.

Dodatni poticaj naučnoistraživačkom radu predstavljao je i vrlo ambiciozni projekat tzv. Društve- 
nih ciljeva, čiji je krajnji rezultat trebao da osigura novi naučni pomladak u zemlji i stvori dobre uvjete za objavljivanje i diseminaciju svih vrsta akademskih radova. Pri tome je posebna pažnja bila obraćana razmjeni knjiga, a naročito časopisa sa brojnim institucijama širom svijeta. Na taj način je pojačavana dvosmjerna komunikacija, a i postignuti efekti su doprinijeli da se kolege širom svijeta upoznaju sa naučnim rezultatima naših istraživača, s jedne, dok su radovi uglednih naučnika iz najznačajnijih svjetskih centara bili dostupni na redovnoj osnovi domaćim autorima, s druge strane. Ne treba sumnjati da su se iz te redovne međubibliotečke razmjene i uvida u tekuću svjetsku akademsko-znanstvenu produkciju dobijale i nove ideje za daljnje prodore u svim disciplinama, a ujedno se podizala i ljestvica očekivanog kvaliteta radova za objavljivanje. Nažalost, ratna kataklizma tokom 1990-ih godina uvelike je razorila i taj dio ovdašnje akademsko-znanstvene infrastrukture te opustošila dotad relativno solidan broj naučnika u svim oblastima istraživanja. U samo nekoliko godina je gotovo zamrla svaka aktivnost na izdavanju brojnih dotadašnjih naučnih časopisa, a novi su nerijetko prestajali s izlaženjem nakon što bi se iscrpila međunarodna pomoć iz prijateljskih država, ili, češće, međunarodnih privatnih fondacija, kao što je bio Fond Otvoreno društvo (Fondacija "Soros"), Konrad Adenauer Stiftung, Pro Helvetia, GTZ te još neke. Bez te neophodne podrške veliko je pitanje da li bi se i u kojem vremenskom intervalu uopće oporavila naučna misao na ovim prostorima. S druge strane, došlo je do nekontroliranog zamaha u otvaranju kako javnih tako i privatnih fakulteta, akademija i univerziteta. Ionako malobrojna misleća skupina preostalih znanstvenika, koji su gotovo svi odreda radili kao univerzitetski nastavnici, u prvoj deceniji 21. stoljeća poprilično se rasula po tim novim institucijama, u kojima nerijetko nije bilo ni osnovnih uvjeta za normalno odvijanje nastave, a kamoli za ozbiljnije naučnoistraživačke djelatnosti. Istina, bilo je nekih sporadičnih pokušaja da se i u tim sredinama pokrenu periodične akademske publikacije, ali su one najčešće ostajale ispod razine iole ozbiljnijih časopisa te nisu uspjele dostići već poprilično razvijene i prilično jasno određene kriterije za vrednovanje te vrste radova u sve bržim globalizacijskim procesima.

\section{Tehnološko-informatičke promjene u svijetu potkraj 20. stoljeća}

Naime, dok je na našim prostorima vladao posvemašnji zastoj zbog rata i poslijeratne infrastrukturne i kadrovske devastacije te, osobito, finansijske oskudice, u svijetu se već dogodila informatičko-kibernetička revolucija. Pojava personalnih računara $\mathrm{i}$ interneta te baza podataka i digitalnih repozitorija uveliko je promijenila dotadašnji pristup ovim ak- tivnostima. Za najrazvijenije zemlje svijeta to je bila prilika da dodatno ojačaju svoje ionako izuzetne ekonomske i akademske potencijale, dok je većina nerazvijenih zemalja grčevito nastojala da se što više primakne kakvom-takvom stepenu naučnog razvoja. U toj su se situaciji ubrzo iskristalizirali i dotad veoma vidljivi znaci zaostajanja za brojem, a još i više za kvalitetom objavljenih radova u zemljama tzv. Trećeg svijeta. U nemogućnosti da sami u relativno kraćem roku prevaziđu te ogromne razlike, već i samim širenjem globalne internetske mreže i sve većeg broja repozitorija svakojakih podataka u digitaliziranim oblicima, postavljeni su, u okviru najprestižnijih razvijenih akademsko-istraživačkih sredina svijeta, novi parametri o vrednovanju svih vrsta naučnih radova, koji su, uz tekuću, novu produkciju na vidjelo sve više počeli iznositi i brojna djela nastala u prethodnim vremenima. Ta sve veća mogućnost da se jednako pristupi i starijim i najnovijim izdanjima naučne produkcije rezultirala je uspostavljanjem strožijih kriterija i u pogledu kvantiteta, a osobito kvaliteta akademskih radova. Naime, umjesto nekadašnjih isključivo štampanih časopisa kao sredstava diseminacije rezultata naučnoistraživačkih aktivnosti, počeli su nicati brojni elektronički časopisi, ili su i oni koji su izlazili u štampanom obliku sve više počeli pribjegavati tzv. elektroničkom izdavaštvu (e-publishing). Budući da je jedan od temeljnih principa globalne informatičke mreže (world wide web /www/ ili Internet) zasnovan na slobodnom postavljanju različitih sadržaja u digitalnoj formi, uz naknadna ograničenja u pogledu onih neprimjerenih objava koje potiču veličanje mržnje po svim osnovama, došlo je do prave eksplozije elektronskih sadržaja širom svijeta.

Kako Internet, bar u tih nekoliko prvih decenija postojanja, zbog nedostataka uobičajenih kataloga $\mathrm{u}$ tradicionalnim bibliotekama, nije osiguravao pregledniji uvid u svu tu silinu sadržaja koje su postavljali i pojedinci i grupe, ali i sasvim određene institucije, na njih su se počeli primjenjivati svojevrsni kriteriji, čijom se dosljednom upotrebom oformila neka vrsta prevalirajućih pravila. U okviru njih su se sistematizirale i vrste stručnih i naučnih radova na prilično jasnoj ljestvici od najjednostavnijih do onih najboljih, a samim tim i najprestižnijih. Među tim kriterijima treba posebno izdvojiti tzv. "faktor uticaja" (impact factor), koji je trebalo da ne samo učvrsti dotadašnju nomenklaturu akademskih radova nego i da ih tretira kao svaki drugi materijalni proizvod, kao intelektualnu robu posve određene vrijednosti. To su prilično rano shvatile upravljačke strukture kompanija koje su razvijale velike baze podataka u cilju zaštite očekivanih vlastitih prihoda, jer je u tom segmentu narastajućeg virtuelnog tržišta trebalo onemogućiti, prije svega, konkurenciju u istoj djelatnosti da se domogne rezultata bez imalo 
ulaganja u poticanje i stvaranje vrijednih naučnih postignuća.

Kako su se razvijale mogućnosti za objavljivanje rezultata u pogledu akademskih publikacija i njihovog kvaliteta, tako su se razvijali i novi alati za mjerenje njihovog uticaja. Međutim, kako oni nisu bili dostupni većem broju istraživača, nego su ostali ograničeni na najrazvijenije dijelove svijeta - istočne $\mathrm{i}$ zapadne Evrope, SAD i Japana - naučnici u drugim sredinama su morali da se oslanjaju na odštampane primjerke u referentnim dijelovima vodećih biblioteka širom svijeta te da mukotrpno popunjavaju vlastite bibliotečke, uglavnom skromne, fondove. Ta praksa je u velikoj mjeri prisutna i danas u većem dijelu svijeta kojem nisu dovoljno dostupni noviji tehnološki, elektroničko-elektronski izvori.

I u tom izuzetno dinamičnom periodu uspona i neslućenog razvoja nauke tokom cijelog 19. i skoro tri četvrtine 20. stoljeća (od)štampani, dakle, objavljeni tekst je imao neprikosnoveni primat nad svakim drugim potencijalnim ili stvarnim izvorom znanja. Čak i najbolje izvedeni i dokazani eksperimenti ili prodori u ona naučna područja koja su dotad bila nezamisliva morali su dobiti valorizaciju u obliku objavljenih rezultata kao teksta - bilo da je u pitanju stručni ili naučni članak, ili, pak, zbornik radova, te, osobito, prestižna monografska publikacija. Takav pristup je proizveo i jednako važnu aktivnost u naučnoistraživačkom procesu kao sastavnom dijelu šire postavljenih odnosa unutar same akademsko-istraživačke zajednice i pripadajućih, pratećih dijelova njenog neposrednog okruženja. To se, prije svega, odnosi na akademsko izdavaštvo, što se postepeno uspjelo nametnuti kao zasebna djelatnost, koja se protezala u različite dijelove šire shvaćene infrastrukture unutar onih vrhova društvene ljestvice kojima je, s razlogom, dodijeljena uloga predvodnika, pokretača razvoja društva uopće, a naročito onih elitnih dijelova što su se odlučili baviti naukom kao jedinom, ili barem pretežnom profesijom.

\section{Kultura i struktura recenziranja u okviru hijerarhije naučnih radova}

U takvom kontekstu se razvila i ideja da su te važne aktivnosti mjerljive baš kao i svaki drugi rad. Međutim, upravo tu se umiješala i ona već ustaljena potreba za prethodnim ocjenjivanjem, recenzijom ili pregledanjem takve vrste proizvoda. Treba se podsjetiti da ovaj termin potiče od latinske riječi recensio $=r e+$ censere, u značenju "prosuditi, ocijeniti, prikazati", čemu odgovara i engleski izraz review. U znanstvenoj terminologiji na engleskom jeziku ovaj izraz se često povezuje sa pridjevom critical (kritički), što ukazuje na poseban pogled u toj vrsti zauzimanja stavova prema određenom dokumentu kao tekstu. Vremenom se uspostavila relativno slo- žena, pa ipak veoma jasna, prateća aktivnost bez koje se više nije mogla ni zamisliti bilo kakva ozbiljnija djelatnost na tom planu. Ona je, slikovito rečeno, postala dobro razrađen sistem zatvorenih, ali međusobno povezanih posuda u okviru ogromnog mehanizma, koji je uspostavio pravila igre u cjelini tog velikog sistema. Vjerovatno slijedom logike intenzivnog razvoja, taj je sistem $\mathrm{u}$ datom trenutku nametnuo svojevrsnu piramidu, podosta nalik na onu koja se uporedo razvijala u industrijskim korporacijama tog doba sa ljestvicom podređenih i nadređenih članova na strogo profiliranoj ljestvici odnosa između pojedinih dijelova tog raznolikog svijeta naučnika i pripadajućih podsistema - od univerziteta, istraživačkih centara, laboratorija, instituta, biblioteka i akademskog / znanstvenog izdavaštva. Oni su se našli u svojevrsnoj simbiozi u čijim su presjecištima bili, upravo, objavljeni naučni radovi kao sastavni dio te relativno nevelike zajednice. I ona se oslanjala na uspostavljenu hijerarhiju odnosa na čijem su vrhu bili oni izvrsni, najbolji po kojima se prepoznaje određena epoha, ali, gotovo isključivo, po iskazanim naučnim rezultatima. A tih rezultata nije moglo biti bez javno dostupnih, objavljenih djela koja su i sâma bila prethodno postavljena na tu ljestvicu na osnovu usvojene nomenklature naučnih i stručnih radova - od kraćeg prikaza do monografske publikacije najveće vrijednosti.

Druga vrsta akademske i izdavačke hijerarhije odnosi se na pretpostavljenu vrijednost radova - kako u pogledu kvaliteta tako i kvantiteta (broja) radova u znanstvenim publikacijama. Recenzirani radovi u takvim časopisima (peer-reviewed journals) nametnuli su neke standarde izvrsnosti njihovim potencijalnim kontributorima. Strogi princip "mora se objaviti kao tekst" u štampanom obliku - Publish or Perish (knjige, časopisi ili specijalna izdanja ili publikacije) bili su i ostali stubovi akademske izvrsnosti i živi dokaz napornog rada koji obavljaju vrijedni akademski djelatnici - naučnici ili znanstvenici pod uvjetom da su njihovi rezultati dostupni širokoj akademskoj i stručnoj javnosti.

Taj pristup je uzdrman u doba globalizacije pojavom elektronskih i internetskih izvora, koji su doveli do prave eksplozije elektronskih periodičnih publikacija sumnjivog kvaliteta, ali su uticali i na strukturu, značaj $i$ akademske profile kako onih koji ih pišu, tako i onih koji ih ocjenjuju. Recenzenti su, po definiciji, shvaćani kao pouzdani evaluatori ili kvalificirani kritičari, koji su u stanju da ponude relativno objektivnu ocjenu naročito za radove koji se odnose na uže definiranu ili interdisciplinarnu oblast. Njihov konačni cilj je održavanje standarda kvaliteta te poboljšanje akademskog ili znanstvenog kredibiliteta autora čiji objavljeni rezultati istraživanja mogu izvršiti uticaj na istu ili sličnu profesiju. Takvo objektivno (pre) ispitivanje pomaže članovima redakcija, glavnim 
urednicima, ili, u konačnici, izdavačima da prihvate rad, zatraže da se popravi ili uradi nova verzija s određenim preinakama, ili u cijelosti odbace (ne prihvate). Tradicionalno je to radilo dvoje ili troje anonimnih stručnjaka, čija je ocjena bila predzadnji korak u postupku objavljivanja rada te kao neka vrsta garancije da se spriječi pojava nepouzdanih, loših, ili posve neprihvatljivih rezultata istraživanja. Danas se sve više zagovara tzv. "otvoreno recenziranje" (open peer review), gdje su komentari i kritike vidljivi autorima, a identitet recenzenata je poznat, ili se bar može doznati, na upit, o kome je riječ. Na sceni je dramatično smanjenje štampanih časopisa, jer se i oni najbolji nastoje prilagoditi standardima elektronskih publikacija, ili će nestati u "ropotarnici historije". Ta poplava elektronskih akademskih časopisa (e-journals) otkrila je i brojne anomalije koje se vezuju za sve veću komercijalizaciju akademskog izdavaštva i gledanje na tu aktivnost kao na bilo koju drugu vrstu posla koji treba da donese samo profit i ništa drugo nego profit. One se odlikuju nizom sumnjivih aktivnosti, čiji je cilj da zavaraju naivne pripadnike akademske zajednice nudeći im naizgled velike pogodnosti u naporu da nađu odgovarajućeg izdavača za svoje radove.

\section{Promjene u krajoliku znanstvene komunikacije}

Te lažne pogodnosti uključuju vrlo često agresivnu marketinšku kampanju prema potencijalnim kontributorima. Desetine e-mail poruka ili promoviranja preko popularnih elektronskih portala ili pretraživača pozivaju autore da pošalju svoje radove dotad maltene nepoznatim izdavačima. Nerijetko se u tim oglasima nude i mjesta u uređivačkim odborima ili redakcijama časopisa, "garantira" se skoro pa automatsko prihvatanje poslanih tekstova i još brže objavljivanje; ali se vješto skriva stvarna lokacija i identitet izdavača. Naziv časopisa ne odražava njihovo stvarno porijeklo, jer je dobro "ušuškan" iza dugačkih i zvučnih naslova koji treba da podsjećaju na uvažene časopise iz neke oblasti. Nazivi kao "Network", "Centre", "Association", "Institute", trebali bi da ukažu na ozbiljnost, iako je u pitanju, najvjerovatnije, samo jedna osoba (društvo jednog lica - d. j. 1., ili one man show), koja se služi zakupljenim poštanskim pretincem, nerijetko iz skromnog sobička u nekoj nedođiji, i uz podršku dva do tri računara putem kojih se obavlja sva ta lažna komunikacija s autorima akademskih radova.

Najčešće se radi o biomedicinskim disciplinama, gdje je ta pojava, prema izvršenim istraživanjima, najčešća a prisutne su i lažne tvrdnje da jedan ili više takvih časopisa ima uključen relevantan faktor uticaja (Thomson-Reuters impact factor). Uprkos opetovanim tvrdnjama, sadržina, u pravilu, NIJE indeksirana u stručnim servisima (osim u možda veoma rijetkim slučajevima) koji se stručno bave tim poslom. Vidljivo je i hvalisanje da časopis ima 'vodeći status' u toj oblasti, što se ne može potvrditi stvarnim dokazima, osobito ako se zatraži pristup ranije objavljenim i arhiviranim brojevima. Na djelu je, doslovno, ona stara engleska izreka: If it seems too good to be true, it likely is (Ako zvuči suviše dobro da bi bilo istinito, onda vjerovatno i nije). To se posebno odnosi na časopise i navodne izdavače koji zagovaraju otvoreni akademski pristup, čime se u velikoj mjeri ova plemenita nakana pretvara u svoju suprotnost. Na tu nakaradnu pojavu se, s razlogom, gleda s velikom dozom sumnjičavosti među čestitim autorima, bilo da potiču iz neposredne akademske ili šire istraživačke zajednice. Mnogi od njih podižu svoj glas protiv takve prakse.

Među tim iskrenim zagovornicima su i oni koji nastoje da sačuvaju i dignitet i kvalitet, kako samih autora tako i njihovih djela. Među njima se posebno ističe Jeffrey Beall, bibliotekar sa University of Colorado, Denver, u SAD. On je tvorac izraza "grabežljivo izdavaštvo otvorenog pristupa" (predatory open access publishing). Ponukan vlastitim iskustvom, jer je iznenada, 2008. godine, dobio niz ponuda od sumnjivih akademskih časopisa da ga uključe u brojne uređivačke odbore, iako je već u primljenim mailovima zamijetio brojne jezičke i gramatičke greške u engleskom jeziku na kojima su pisane te poruke, Beall je veoma sistematično istraživao sve veći broj takvih nepoštenih izdavača i počeo da redovno objavljuje liste tih i takvih potencijalnih ili mogućih grabežljivih izdavača. Budući da je svake godine uredno ažurirao svoje liste, broj tih sumnjivih izdavača se, od prvih 18 u 2011. godini, popeo na 923 u decembru 2016. Po njegovoj procjeni, ti navodni izdavači sada objavljuju prosječno oko 5-10\% ukupne akademske produkcije otvorenog tipa godišnje, dok je objektivno procijenio da oko $25 \%$ časopisa koji zagovaraju otvoreni pristup, u stvari, spada u tu kategoriju sumnjivih i grabežljivih izdavača. Iz tog razloga je objavio brojne tekstove u kojima ne samo razotkriva brojne primjere te nekorektne prakse nego i upućuje na to kako da se prepoznaju takvi izdavači i kako da se izbjegne da se padne u njihovu zamku:

Ocjenjivanje izdavača akademskih časopisa otvorenog pristupa je proces koji uključuje pomno, oprezno i cjelovito, a ponekad i skeptično ispitivanje izdavača u pogledu sadržaja, prakse i internetskih stranica: kontaktiranje izdavača, kad za to postoji potreba, čitanje izjava autora tih izdavača o njihovim iskustvima s izdavačem te utvrđivanje stanja o tome da li je izdavač posegnuo za bilo kojom od sljedećih praksi za koje se zna da su ih počinili nepošteni grabežljivi izdavači, ispitivanje svih dodatnih kredibilnih dokaza o izdavaču, kompiliranje veoma važnih povratnih informacija iz "zakulisnih kanala" od 
strane akademskih i naučnih autora i uzimanje $u$ obzir suprotnih povratnih informacija od samih izdavača. (Beall 2015)

$\mathrm{Na}$ te zamke se lako "upecaju" mnogi koji se bave ovom vrstom posla. Treba se podsjetiti da je konačni cilj bilo kojeg akademskog djelatnika / naučnika ili znanstvenika, te istraživača uopće, da stekne i zadrži normalan, relativno dobro plaćen posao u instituciji koju finansijski podržava ili država, ili neka privatna zaklada, ili, pak, neka solidna komercijalna firma. Drugi ideal je da se veći dio svog slobodnog vremena provede u udobnosti svog doma čitajući i razmišljajući o stvarima koje su se našle u središtu njihovog istraživanja ili razmatranja. Dio tog procesa se tradicionalno veže za ustanove koje sadrže velike zbirke ili količine znanja (knowledge repositories), kao što su instituti, biblioteke, klinike, laboratoriji ili naučni centri, visoko specijalizirani za takve djelatnosti. Sâm čin pisanja se obično i odvijao u svojevrsnoj izdvojenosti, izolaciji od "vanjskog" svijeta - ili u vlastitoj radnoj sobi, ili, češće, u akademskoj sredini, u kabinetu na nastavnoj ili istraživačkoj ustanovi, te i u tada najboljem intelektualnom okruženju - među knjigama, časopisima i drugim dostupnim štampanim izvorima u nekoj prestižnoj biblioteci. I u takvoj sredini se podrazumijevala upravo ta izdvojenost, svojevrsni drugačiji stav, koji je odgovarao ustaljenoj slici zanesenog naučnika koji kao da nije svjestan svijeta u kojem se nalazi. Treba podsjetiti da je takva slika bila pandan razbarušenom, boemskom pjesniku iz doba romantizma, također izdvojenom i usamljenom, ali nadasve izuzetno nadarenom pojedincu. Uostalom, von Humboldtovo shvatanje i jednog i drugog tipa ovih kreativnih usamljenika i nastalo je upravo u doba punog zamaha romantičarske poezije, u prvim decenijama 19. stoljeća.

\section{Kreativne profesije}

Nekih 150 godina kasnije, počela se uobličavati slična intelektualna konstrukcija u zapadnom svijetu. Dotadašnja opća podjela na manuelne $\mathrm{i}$ intelektualne radnike, "plave" i "bijele" mantile (blue vs. white collars) dodatno se modificirala, jer je prodorom u svemir i sve bržim razvojem visokosofisticiranih tehnologija postalo očigledno da se stvara novi sloj visokostručnih pojedinaca, koji su u stanju da svojim otkrićima i izumima uvedu svijet u novu tehnološku eru. Vremenom se ukazala potreba da se te najkreativnije umove pokuša smjestiti u posebnu kategoriju tzv. kreativnih profesija. Ne treba da čudi da je tada nastala ideja o "društvu znanja" u doglednoj budućnosti, koja će se i dogoditi s naglim razvojem informacijsko-digitalnih tehnologija u posljednjem kvartalu 20. stoljeća. Ona je potvrdila smjele pretpostavke Thomasa Kuhna o slijedu i smjeni naučnih revolucija, koje neminovno dovode do nove tehno- loške, a time i sveobuhvatne promjene društvene paradigme. U takvom kontekstu se nametnuo koncept definiranja mislećeg kolektiva, zajednice većeg broja znanstvenika i njihove stalne međusobne saradnje i razmjene informacija u cilju postizanja što većih $i$ što kvalitetnijih naučnih rezultata. Dijeljenje znanstvenih podataka putem knjiga ili članaka u časopisima je bilo odveć sporo u vremenu kada su u direktnom TV-prenosu ljudi slijetali na Mjesec, ili se prenosili "uživo" svjetski sportski događaji ili masovni humanitarni muzički koncerti (Band Aid).

T. H. Davenport je 2005. definirao "znanstvene radnike kao one koji misle da bi zaradili za život (think for a living) i imaju viši stupanj znanja obrazovanja i iskustva, a primarni cilj njihovog posla uključuje stvaranje, distribuciju i primjenu znanja" (Davenport 2005, 9). Jedan od najvećih svjetskih marketinških stručnjaka Peter Drucker je nešto ranije, 1999. godine, ustvrdio: "Najveća vrijednost institucije u 21. stoljeću, poslovne ili neke druge, bit će znanstveni radnici i njihova produktivnost." (Drucker 1999, 135). U te profesije spadaju vrhunski stručnjaci kao što su specijalisti koji razvijaju software, ljekari, pravnici, izumitelji, učitelji, finansijski analitičari i arhitekti. Valja zapaziti da su na prvom mjestu navedeni znanstvenici koji razvijaju računarske programe, bez kojih bi bio nezamisliv trenutni prijenos informacija nepreglednom broju istovremenih korisnika, a time i znanje koje te informacije u vidu metapodataka prenose do gotovo svakog čovjeka koji ima tehničke mogućnosti da im pristupi te dovoljno znanja i vještine da ih može konsultirati i kreativno koristiti.

\section{Akademska komunikacija danas}

Sve veća količina znanja koja nam postaje dostupna kroz nepregledne kibernetičke prostore mijenja ranije ljudsko poimanje sistema brojčanih vrijednosti. Kompleksnost količine informacija postaje glavna prepreka tradicionalnom poimanju znanstvenika koji je bio u stanju da se $\mathrm{s}$ njom nosi na smislen način u ne tako dalekoj prošlosti. Čak ni um nekog znanstvenika više nije u stanju da procesuira toliku raznovrsnost informacija u nepregledno dostupnim izvorima bez nekih bitnih pretpostavki. Bez dobrog vođenja kroz kibernetički univerzum može se desiti da putujemo godinama, pa i decenijama, a da nikad ne stignemo na željenu destinaciju. Verzije online kataloga sve više zamjenjuju tradicionalne bibliotečke kartične kataloge, a time se ruši i ideja biblioteke kao čvrste zgrade koja se stalno popunjava novim izvorima saznanja, što ima sve manju ili nikakvu vrijednost za istraživača.

Bez jakog prenosnog i stacionarnog računara i pripadajuće opreme sa velikim memorijskim kapacitetom (memory disk, CD, DVD, memory stick ili flash me- 
mory, eksterni hard disc) te kućnog štampača ne da se ni zamisliti savremeni istraživač, a kamoli autor. Tri vrste takve opreme su neophodne za rad: kod kuće, na poslu i u transportu od kuće do posla i nazad, ili na putovanjima na stručne i akademske skupove $u$ zemlji i svijetu. Ono što smo nekad pamtili u glavi, ili pisali ili bilježili na papiru, te nosili sa sobom u velikim kožnim torbama ili koferčićima (nekoliko dokumenata, možda časopis, koju knjigu ili fotokopirani materijal) sada, uglavnom, ostaje u kući ili na poslu, jer se ogroman broj informacija pohranjuje na osobnim, ličnim mašinama (personal machines), a do njih se može brzo doći uz pomoć Interneta, u slučaju potrebe. Prisutnost IT mašina ili, sve više, manjih digitaliziranih spravica (gadgets) smatra se neophodnim za takve poslove, što uključuje laptope, palmtope, Ipade, pametne telefone sa nizom funkcija, koji moraju imati veliku memoriju, brzi internet i brojne komunikacijske integrirane funkcije i dodatnu opremu. Stalna ili neprekidna mogućnost komunikacije, dostupnost izvora podataka u realnom vremenu, a da se pri tome ne gubi njihova dostupnost, te pohranjivanje za kasniju analizu ili upotrebu u bilo koju svrhu uključuje sigurnu, brzu i neprekidnu internetsku vezu, pažljivo odabiranje podataka i pohranjenih informacija u tom ogromnom repozitoriju znanja te i specifično i odabrano područje istraživačkog interesa. Iako je ogromna većina čovječanstva ne samo prihvatila nego i masovno koristi ove blagodati, opet su se pojavile i određene dvojbe o tome kako da se izbjegne svojevrsna anarhična eksplozija tih aktivnosti u realnom vremenu

To nas dovodi i do pitanja izbora internetskih tražilica, alata, platformi i web portala ili stranica koji se mogu koristiti da se dođe do rezultata vrijednih tzv. dobre nauke ('good'science), gdje "dobro" uglavnom znači pouzdan i standardiziran ciklus istraživanja, koji se može reproducirati na transparentan i naučno korektan način. Međutim, nisu svi znanstvenici bili oduševljeni kako tim nevjerovatnim ubrzanjem načina života, tako i sve većim pritiskom da se jednako, ako ne i mnogo više, ubrza naučnoistraživački rad. Neki od njih su to uporedili sa sve većom upotrebom gotove, tzv. brze hrane (fast food) naspram brižljivo pripremljenih jela koja se kuhaju više sati da bi se zgotovila osobito ukusna hrana. I kao što ima dosta zagovornike tzv. "spore hrane" (slow food), tako se 2010. pojavio i "Manifest spore nauke" (Slow Science Manifesto). Njegovi zagovornici su na simpatičan, skoro pa neobavezan način ukazali na osobenosti tadašnjeg akademsko-znanstvenog krajolika i svoju ulogu u njemu:

Mi smo naučnici. Mi ne vodimo blogove. Mi se ne služimo twitterom. Mi uzimamo onoliko vremena koliko nam je potrebno.

Nemojte nas krivo shvatiti - mi podržavamo ubrzani razvoj nauke na početku 21. stoljeća. Mi podržavamo stalni protok recenziranih časopisnih publikacija i njihov uticaj, mi podržavamo naučne blogove i medije i potrebu za promocijom; mi podržavamo povećani stepen specijalizacije i diversifikacije u svim disciplinama.

Mi, također, podržavamo da se rezultati istraživanja vraćaju u zdravstvenu zaštitu i budući prospertitet.

Svi smo mi u toj igri. (Willis 2013, 2)

\section{Scholarly Commons}

A ko je sve to "u igri"? Nedavno je (2016. godine) obavljeno veliko globalno istraživanje, koje su koordinirali Jeroen Bosman i Bianca Kramer iz Nizozemske (Utrecht University Library). Rezultati su prikupljeni od 20.663 anketirana znanstvenika sa svih kontinenata, $i$ to tako što su se oni spremno odazvali na poziv da sudjeluju u velikoj anketi čiji je cilj bilo ne samo utvrđivanje približnog broja profesionalnih pripadnika "društva znanja" nego i analiza brojnih faktora koji utiču na njihov rad. U skladu sa preovlađujućim kriterijima za utvrđivanje takve statistike, sačinjen je relativno pouzdan reprezentativni uzorak, koji je pokazao brojne slabosti na globalnom planu, naročito među nerazvijenim zemljama, gdje i dalje prevlađuju tradicionalni štampani časopisi u kojima se objavljuju akademski radovi. Daleko je poraznija bila činjenica da se skoro $90 \%$ i više tih radova konsultira, odnosno čita, u vrlo ograničenom krugu korisnika, pretežno ili čak isključivo u krugovima mlađih, još neafirmiranih istraživača, koji ih koriste kao reference za svoje radove, ili kao dio uobičajene metodološke aparature za pripremu radova za objavljivanje. Taj trend je prisutniji u Latinskoj Americi, Africi i Aziji, te još ponegdje u nekadašnjoj istočnoj Evropi. U razvijenom svijetu je situacija značajno drugačija kad su u pitanju autori akademskih radova.

Oko $80 \%$ njih radi u akademskoj zajednici i odražava sadašnje trendove u pejzažu znanstvene komunikacije. Osim poznatih baza podataka, kao što su Web of Science, Scopus, Elsevier, PubMed, World Cat, te pretraživača kao što su Wikimedia ili Google, oni se služe i izvorima kao što su Mendeley, Paperity, SpringerNature ili Digital Science u okviru baze Holtzbrinck te mnoge druge. I ogroman broj drugih, ne tako poznatih e-platformi (i-resources) koje pohranjuju i dijele podatke i publikacije otkrili su potrebu za novim modelom akademske komunikacije: Good, Efficient and Open (G-E-O) - dobar, efikasan i otvoren. Zagovornici takvog pristupa promoviraju znanstveni komunikacijski ekosistem za istraživačke aktivnosti u 21. stoljeću, koji nazivaju "Akademsko-istraživačko zajedničko dobro" (Scholarly Commons). 


\section{Kratak pregled nastanka i razvoja ideje otvorenog pristupa}

Ona nije zamišljena kao jedinstvena platforma ili alat, nego kao skup principa, dobre prakse standarda i poprečnih veza (interfaces), koji trebaju da usmjere tok znanstvenih aktivnosti u raznim pravcima kroz sve faze istraživačkog procesa - od zamisli, preko istraživanja pa sve do konačne izvedbe $i$ diseminacije. Krajnji cilj je bio da se definira skup protokola, principa, formata i drugih normi koji će omogućiti da svaka vrsta istraživanja slobodno kola među naučnicima koji žele da daju svoj doprinos, ponovo koriste, komentiraju ili unaprijede te procese, te da budu referencirani na jednostavan način. U okviru sada već dobro razvijenih alata i protokola pokušao se smanjiti, pa čak i premostiti duboki formalnopravni raskol između autora i izdavača $u$ odnosu na vrstu izdavanja i mogućnosti korištenja licenci kojima se uređuje ta prilično zamagljena oblast. Licence se uglavnom tiču atribucije, dopuštanja mogućih izmjena, komercijalne upotrebe takvih radova, kao i obaveze daljnje diseminacije tog novog rada pod okolnostima koje propisuje ta licenca. U novije vrijeme se ta oblast pokušava što bolje urediti, te su se pojavile i vrlo pristupačne inačice na raznim jezicima, koje treba da olakšaju autorima bolje snalaženje u tom administrativno-pravnom okviru Creative Commons.

Ova platforma je i nastala kao posljedica ranijih inicijativa za uspostavu otvorenog pristupa akademskim djelima. Njih su naročito pokušali da definiraju dokumenti o pristupu znanstvenim informacijama, od kojih su najpoznatiji Budimpeštanska inicijativa o otvorenom pristupu (Budapest Open Access Initiative) 2002, Bethesdantska izjava o otvorenom pristupu (Bethesda Statement on Open Access Publishing) 2003. i Berlinska deklaracija o slobodnom pristupu znanju u prirodnim, društvenim i humanističkim znanostima (Berlin Declaration on Open Access to Knowledge in the Sciences and Humanities) 2003. godine. Kasnije su se tom materijom bavili i neki drugi, bitni dokumenti, poput Budimpeštanske deklaracije o pravu na pristup informacijama (Budapest Declaration on the Right of Access to Information 2008) i Izjave IFLA o otvorenom pristupu (IFLA Statement on Open Access 2011). Tome su posvećena i Načela i preporuke za pristup istraživačkim podacima nastalim u okviru istraživanja finansiranih iz javnih izvora (OECD Principles and Guidelines for Access to Research Data from Public Funding 2007) i Preporuke o pristupu i očuvanju znanstvenih informacija (Communication from the European Commission: "Towards Better Access to Scientific Information: Boosting the Benefits of Public Investments in Research" 2012).

Već je u Budimpeštanskoj inicijativi jasno naznačeno da "otvoreni pristup" treba da omogući čitanje tekstova bez ograničenja te njihovu ponovnu upotrebu kod izvođenja nastave i pri pisanju akademskih radova, a da pri tome pažljivo razriješe i na odgovarajući način definiraju pitanja autorskih prava, pohranjivanja i mašinske čitljivosti tih radova putem objavljivanja dokumenata u odgovarajućem pdf formatu (http://www.budapestopenaccessinitiative. org/). Ovaj dokument je otvorio široke mogućnosti istraživačima i pripadnicima akademsko-naučne zajednice u pogledu pohranjivanja, arhiviranja vlastitih, prethodno recenziranih radova (self-archiving) $\mathrm{u}$ referentnim otvorenim elektronskim arhivima, koji se pridržavaju uspostavljenih standarda što ih je potakla ova inicijativa. S druge strane, ideja časopisa otvorenog pristupa (Open-Access Journals) trebalo je da ako ne baš ukine naknadu za pristup tim izvorima, a ono barem da iznađe druge izvore finansiranja, koji bi, u konačnici, osigurali novac za naknadu prilježnim recenzentima za njihov intelektualni trud te i pokrili troškove objavljivanja (http:// www.soros.org/openaccess).

Otvoreni pristup (engl. Open Access, akronim: OA), stoga, može se pokušati definirati i kao slobodan, besplatan i neometan mrežni pristup digitalnim znanstvenim informacijama koji omogućava čitanje, pohranjivanje, distribuciju, pretraživanje, dohvaćanje, indeksiranje i/ili drugo zakonito korištenje mnoštva, ako ne baš i svih vrsta prvenstveno akademskih, ali $\mathrm{i}$ drugih radova. $\mathrm{U}$ njih spadaju $\mathrm{i}$ članci, obično u specijaliziranim časopisima, sâmi časopisi kao izvor informacija, elektronske / digitalizirane knjige, sve vrste formalnih radova (magistarske i doktorske disertacije (e-theses) te sve druge savremene forme - prezentacije (naročito one u popularnim formatima, kao što su Powerpointu ili Prezi), audio i video isječci, podkasti i sl. Slobodan u ovom kontekstu znači trajno slobodan od bilo kakvih ograničenja i postavljanja uvjeta za pristup i korištenje. O tome se na ovim prostorima vrlo jasno odredila Hrvatska deklaracija o otvorenom pristupu, 2012. godine (http://www.fer.unizg.hr/oa2012/ deklaracija). Nju su potpisali istaknuti zagovornici otvorenog pristupa, među kojima i akademici Leo Budin i Vlatko Silobrčić, te nekadašnji ministar znanosti prof. dr. Gvozden Flego.

\section{Pristup i politika otvorenog pristupa (The Open Access Policy)}

Još od temeljnih načela iskazanih u Budimpeštanskoj inicijativi vodi se rasprava o tome da li je otvoreni pristup doista otvoren $u$ potpunosti, bez ikakvih ograničenja, ili se, ipak, moraju predvidjeti određene situacije u kojima će se iskazati prijeka potreba za nekom vrstom restrikcije.

Postoje mnogi stupnjevi i vrste šireg i lakšeg pristupa izvorima. Pod "otvorenim pristupom" 
ovim izvorima mislimo na slobodan dostup na javnim internetskim mrežama, koji omogućava bilo kojem korisniku da čita, preuzima, kopira, distribuira, štampa, istražuje ili se povezuje sa tekstom ovih članaka u cijelosti, preuzima ih radi indeksiranja, prebacuje ih kao podatke na software, ili ih koristi za bilo koju drugu zakonitu svrhu, bez finansijskih, zakonskih ili tehničkih ograničenja, osim onih koje su neodvojive od samog pristupa Internetu. Jedino ograničenje kod reprodukcije i distribucije i jedina uloga autorskog prava u ovom domenu jeste da se autorima omogući da kontroliraju integritiet (cjelovitost) svog rada i pravo da im se na odgovarajući način prizna autorstvo i da ih se na isti način i citira. (http://www.budapestopenaccessinitiative.org/)

U teoriji bi bilo moguće dosegnuti skoro pa apsolutnu otvorenost svih navedenih, pa i onih budućih, zasad nepostojećih ili nepoznatih izvora kada bi se postigao dogovor o tome ko će snositi troškove realiziranja ove plemenite ideje. Budući da se ni najizdašniji filantropi današnjice, poput Billa Gatesa, Warrena Buffeta ili Georgea Sorosa, ne bi mogli obavezati, čak ni kao konzorcij najbogatijih pojedinaca, da pokriju, doslovno, sve moguće baze podataka, ideja apsolutno otvorenog pristupa morala je biti modificirana. Njena potpuna suprotnost je "zatvoreni" pristup (closed access), dok je prihvatljivija verzija poluotvorenog pristupa (semi-closed access). Zatvoreni pristup je nalik na danas široko rasprostranjenu uslugu kreditnih kartica ili digitalnih audio i video zapisa. Korisnik može pristupiti izvoru informacija kroz vremensku pretplatu (najčešće godišnju, ali se nude i kraći vremenski rasponi), ili se može odlučiti na plaćanje pojedinačnog dokumenta, ili više njih. I dok stotine miliona ljudi ne može zamisliti iole ozbiljniju kupovinu nekog predmeta ili usluge bez kreditne kartice, a skoro pa isti broj korisnika svakodnevno plaća da gleda sportske prenose, filmove ili TV-serije, čini se da umni, intelektualni proizvodi nisu tako poželjna roba. Nekako se očekuje da neko drugi plati za njihovo korištenje - uglavnom bi to trebale da budu institucije gdje su zaposleni istraživači i naučnici, bilo da se radi o privatnim ili javnim pravnim licima. Drugu vrstu pogodnosti nude vlasnici baza podataka i određene periodične publikacije kada se "odriču" visokih cijena pretplate ili pojedinačnog korištenja kroz različite vidove prilagođenih cijena u nerazvijenim zemljama. Naravno, svuda su prisutni nesmiljeni zakoni tržišta te i ove dobrohotne sheme smanjivanja cijena imaju za krajnji cilj vezivanje budućih korisnika i stabiliziranje, a potom i širenje tog segmenta "intelektualnog" tržišta. Kada ono dosegne željene brojke, te će pogodnosti nestati preko noći, jer će kupovna moć sada već redovnih korisnika moći da podnese potrebu da se svakodnevno služe izvorima podataka i za njih plaćaju predviđeni iznos.
Sve ove finansijske i druge nepogodnosti potakle su zagovornike otvorenog pristupa da iznađu (ili zaobiđu!) veoma maštovite načine putem kojih će, u konačnici, biti u mogućnosti da pristupe izvorima bez plaćanja. Ti su načini usporedivi sa sistemom korištenja kreditnih kartica, pa se susrećemo sa varijacijama poput:

- zeleni put (green road) - što podrazumijeva samoarhiviranje radova u institucijskim repozitorijima, na mrežne stranice autora, ustanove i sl.

- zlatni put (golden road) - uključuje razne vrste elektroničkih časopisa

- platinasti ili dijamantski put (platinum or diamond road) - u kojem se članci objavljuju kroz online platforme i dostupni su bez plaćanja autorima tekstova, njihovim matičnim institucijama i bibliotekama, te relativno širem broju specijaliziranih čitalaca

- hibridni put (hybrid road) dozvoljava pristup samo onim člancima u časopisima za koje je prethodno uplaćena pretplata od strane autora ili osnivača tih publikacija.

U većini slučajeva je isključena komercijalna upotreba ili ponovno korištenje radi sticanja finansijske ili neke slične dobiti (profita), a izdavači naplaćuju samo troškove objavljivanja, odnosno štampanja. Zbog neprestanog širenja uticaja sve brojnijih zagovornika otvorenog pristupa, čak su i najtvrđi izdavači morali popustiti u svojim nastojanjima da se u potpunosti domognu autorskih prava vezanih za politiku pohranjivanja i potonjeg rasprostiranja (diseminacije) cjelovitih tekstova koje su objavili u časopisima pod svojom kontrolom. Vjerovatno je to bio rezultat svojevrsnog kompromisa između autora i izdavača, koji je doveo do uređivanja međusobnih odnosa u pogledu mogućnosti samoarhiviranja neke od verzija određenog rada. U tu kategoriju spadaju tradicionalni akademski radovi, kao što su završni, rjeđe dodiplomski, ali obavezno završni diplomski (predbolonjski magistarski ili bolonjski master radovi - final diploma papers), a osobito doktorske disertacije, kao i sve vrste stručnih i naučnih radova, podaci koji se objavljuju nakon izvršenih istraživanja (engl. datasets) te i poglavlja u knjigama, objekti učenja i raznovrsni multimedijalni zapisi. U najvišu kategoriju spadaju sve vrste elektronskih izdanja, bilo da su u pitanju izvorno objavljene e-knjige (ebooks), ali i naknadno digitalizirane knjige.

Budući su u pitanju različiti stepeni dovršenosti nekog rada, koji se neminovno mijenja tokom procesa izrade, u praksi se ustalila sadašnja klasifikacija radova. Ona ukazuje na vezanost određene verzije rada za postupak recenziranja, jer je izvjesno da je radna verzija rukopisa koji je dostavljen na recenziju (engl. preprint; submitted manuscript) u neku 
ruku manje vrijednosti od one situacije kada je rad već dobio pozitivnu ocjenu od strane recenzenata $i$, uz određene manje preinake ili ispravke, može biti prihvaćen za objavljivanje (engl. postprint; accepted manuscript). U toj fazi je rad nesporno i gotovo isključivo u "vlasništvu" autora, ali, kada bude objavljen u obliku kako to odluči izdavač, onda je na djelu svojevrsni prijenos autorstva, jer je ta zvanično objavljena verzija rada, obično u PDF formatu (engl. publisher's version), finansijskim, organizacijskim i drugim vrstama poslovnih aktivnosti izdavača dobila i drugačiju vrstu prava na njeno dalje korištenje. Takve vrste radova obično se ne mogu samoarhivirati u obliku otvorenog formata ili pristupa $u$ institucijskim repozitorijima, jer izdavači, s razlogom, očekuju neku vrstu povrata uloženih sredstava ili kompenzaciju za svoj udio u omogućavanju takvom rukopisu da bude objavljen. Iz tih razloga je najveći kamen spoticanja bio upravo u oblasti potpunijeg definiranja "prava na rukopis/ rad" u nekoj od pomenutih verzija. Očigledno je da autoru pripadaju određena izvorna prava, ali ih on/a, svojom voljom, prenosi u datom trenutku na izdavača. Zbog toga treba biti oprezan kad se govori o "pravu na autorstvo" i o "pravu na korištenje djela", jer je u prvom slučaju u pitanju ono tradicionalno "autorsko pravo", kako ga je još početkom 18. stoljeća definirao prvi pravni akt te vrste (the Statutes of Anne 1709), dok je u potonjem u pitanju "pravo izdavača". Naravno, postoje i one baze podataka ili repozitoriji, odnosno pouzdaniji mrežni servisi, koji pomažu autorima da se lakše snađu u toj kompliciranoj pravnoj priči.

Takav je, na primjer, britanski portal SHERPA/RoMEO, koji redovno prati pristup pojedinih izdavača ili periodičnih publikacija u pogledu otvorenog pristupa te upoređuje njihove stavove $\mathrm{i}$ interpretira tako dobijene podatke kako bi pružio cjelovitu informaciju o tome kako se mogu pohraniti radovi i pri tome sačuvati otvoreni pristup njihovom kasnijem korištenju. Ovaj mrežni servis je razvrstao izdavače $\mathrm{u}$ četiri boje, $\mathrm{u}$ zavisnosti od toga kako se oni ponašaju odnosu na samoarhiviranje cjelovitih tekstova radova u digitalnom okruženju:

1.zeleni izdavači - dopuštaju arhiviranje rukopisa i prihvaćenih rukopisa

2.plavi izdavači-dopuštaju arhiviranje prihvaćenih rukopisa, ali ne i rukopisa

3.žuti izdavači - dopuštaju arhiviranje rukopisa, ali ne i prihvaćenih rukopisa

4.bijeli izdavači - arhiviranje nije dopušteno (http://www.sherpa.ac.uk/romeo/ 2006).

\section{Prednosti i nedostaci otvorenog pristupa}

Pod pretpostavkom da su se pomenute pravnovlasničke zavrzlame razriješile te da su ih prihvatili svi sudionici u tom veoma interaktivnom procesu, treba, napokon, iznijeti prednosti i nedostatke otvorenog pristupa. Ma koliko je, u osnovi, svaki naučni rad rezultat pojedinca ili skupine prethodno okupljenih osoba u istraživački tim, u otvorenom pristupu se njegova sadržina definira na institucionalnim razinama, odnosno putem zajednice istraživača i znanstvenika koji se bave tim ili sličnim poslom. Za njih se pretpostavlja, a to se da relativno lako utvrditi, da posjeduju potrebna kvalitetna znanja iz date oblasti, a njihovo prethodno iskustvo im omogućava da objektivnije ocjene dostavljene radove. Pri tom se značajno proširio ne samo broj nego i vrsta tih radova, u zavisnosti od toga da li su nastali kao dio akademskih obaveza kako studenata tako i njihovih nastavnika, ili su dati na uvid ocjeni stručne naučnoistraživačke / akademske javnosti bez obzira na stepen dovršenosti tih radova. Osim toga, to sakupljanje, arhiviranje, kumuliranje svih tipova radova postavljenih u elektroničke repozitorije je trajan proces. On omogućava svakom potencijalnom istraživaču i/ili autoru svakodnevni slobodni pristup tim materijalima $\mathrm{u}$ okviru golemih globalnih mreža, koje su stalno otvorene (online servisi) i funkcionalne. Svakom pojedinačnom istraživaču omogućava da u tim institucionalnim repozitorijima, kao nekoj vrsti centralnih arhiva, pohranjuje svoje radove te da pomoću njihovih servisa omogućavaju i sebi drugima da im pristupe i koriste ih bez ograničenja. Baš ta brzina i dostupnost utiču na povećanje stepena rasprostranjenosti i uticaja koji ti radovi potencijalno imaju. Osim toga, zbirka tih radova, koja se neprestano povećava $\mathrm{i}$ ažurira, može poslužiti i kao svojevrsni pregled aktivnosti pojedinih autora, te se može shvatiti i kao potpuni znanstveni životopis $(\mathrm{CV})$. S druge strane, otvoreni pristup povećava vidljivost i ugled pojedine institucije, jer joj omogućava da se bolje pozicionira u okviru sličnih organizacija koje vide kao konkurenciju. Posve je jasno da će upravljačka tijela tih institucija iskoristiti brojne prednosti otvorenog pristupa da se reklamiraju i na taj način privuku što kvalitetnije zaposlenike, a $\mathrm{u}$ akademskim sredinama i najtalentiranije studente i profesore. Takva vidljivost može privući i potencijalne ulagače ili donatore te poslužiti i kao važna referenca u natječajima za finansiranje većih projekata iz kojih će proisteći novi i bolji naučni radovi. U neku ruku se na ovaj način standardizira proces ocjenjivanja i samih radova $i$ istraživačkog procesa, što je važno u njihovom administrativnom segmentu. Nije rijetkost da se 
učesnici takvih natječaja žale na netransparentnost ili na subjektivnost ocjenjivačkih komisija, kada njihovi prijedlozi ne zadovolje kako formalne, tako, i još više, ni one bitne vrednosne kriterije po kojima broj radova u međunarodno referentnim bazama $\mathrm{i} / \mathrm{ili}$ njihova citatnost postaju jedan od važnijih elemenata u postupku ocjene važnosti i vrijednosti tako koncipiranih projekata.

Naravno, mogu se navesti i određeni nedostaci otvorenog pristupa. Osim stanovitih izdataka koji nastaju zbog nesklada između shvatanja autorskih i izdavačkih prava te potrebe da se i autorima i izdavačima omogući korektna nadoknada, svakako je cijena pristupa, osobito onima sa skromnim finansijskim mogućnostima, ograničavajući, ako ne i presudni faktor zbog kojeg im mnogi izvori ostaju zatvoreni. Pored toga, može se pretpostaviti da će se otvorenost dostupnih radova nerijetko i zloupotrebljavati u smislu plagiranja ili preuzimanja zasluga od onih kojima one doista i pripadaju. $\mathrm{Ne}$ bi se trebalo bojati da će dominacija elektroničkih izvora posve potisnuti, ako ne i dokinuti, štampane verzije izvora podataka. Prije će biti da će se nekadašnje biblioteke morati transformirati od svojih "muzejskih" karakteristika u mjesta interaktivnog istraživanja. Drugim riječima, morat će se desiti svojevrsna simbioza štampanih i elektroničkih djela $\mathrm{u}$ relativno bliskom vremenu koje je pred nama.

\section{Budućnost?}

A kakva će izgledati ta bliska budućnost? Knjige, časopisi te svaki drugi oblik (dosad) odštampanih materijala bit će definitivno i korišteni isključivo u svojim raznovrsnim elektronskim formatima, iako će neki printani vidovi knjiga još neko vrijeme postojati, više kao znak prestiža. Iako većina istraživača iz srednje i starije generacije i dalje tvrdi da i dalje više vole da koriste štampani tekst, i oni će se morati prebaciti na oblike e-media u vidu dostupnih čitača (e-reader), kao što su sada Kindle, Nook, Booken, Icarus, Kobo, Onyx, Pocketbook ili Tolino.

Alati i platforme za istraživanje (research e-tools and platforms) će se vjerovatno jako širiti u pogle$\mathrm{du}$ dostupnosti i otvorenog pristupa (open access), kao i u pogledu pružanja mogućnosti za besplatno korištenje, čime bi se smanjile zakonske i druge finansijske restrikcije u pogledu korištenja njihovih ogromnih kapaciteta za pohranu podataka. Bit će mnogo više istraživačkih aktivnosti, čak i u humanističkim disciplinama, jer će pojedinačni samostalni naučnik postati rijetkost kao i neko drago kamenje ili stare knjige. Proaktivna saradnja znači da će na djelu biti fleksibilna podjela zaduženja, budući da će se neki dijelovi projekata dodjeljivati manjim timovima znanstvenih radnika (knowledge workers), a njihov će se doprinos moći vidjeti u konačnom izvještaju u potonjim publikacijama. Iz tog razloga ćemo sve više viđati oznaku "kontributori" (contributors), a ne neophodno i "autori" (authors).

Doći će do velikih promjena u pogledu formata završnih izvještaja projekata i akademskih publikacija. Umjesto dosadašnjih cjelovitih ili skraćenih bibliografskih referenci (fusnote, endnote, bilješke u tekstu) u bilo kojem stilu citiranja (MLA, CSA, APA, Harvard, Vancouver), više će se koristiti hyperlink u kojem će se nalaziti potrebna količina potrebne bibliografske informacije, a stvarni izvori će se moći direktno "povlačiti" iz baza podataka, uključujući korisne linkove koji se mogu koristiti odmah ili nekom kasnijom prilikom, kada se rad bude sređivao u konačnoj verziji za objavljivanje.

Akademsko pisanje će se ocjenjivati u pogledu originalnog doprinosa i/ili otkrića, ali i na osnovu toga kako lako se može do njega doći, provjeriti reference, uključujući i faktor uticaja citatnosti (citation impact) ili drugi mjerljivi uticaj koji takav akademski rad može proizvesti u okviru direktne ili pridružene grupe ili zajednice istraživača koji zajedno rade na rješavanju pitanja od općeg ili zajedničkog interesa.

Budući recenzenti (peer reviewers) u okviru sistema otvorenog pristupa moći će da komuniciraju sa svim autorima i da razmjenjuju svoje stavove i mišljenja o dostavljenom radu. Na sličan način će se razviti sistem bodovanja u pogledu i kvantiteta i kvaliteta dosegnutih akademskih, znanstvenih i istraživačkih aktivnosti kako bi se primijenili kriteriji ocjenjivanja (assessment criteria), o kojima je postignuta opća suglasnost, kao standardiziranih alata za mjerenje i evaluaciju svih vrsta akademskih publikacija.

Akademski i naučni skupovi sve će više biti u vidu online konferencija, iako će i dalje biti prostora za međunarodne kongrese, simpozije, radionice ili konferencije, gdje će se znanstvenici pojavljivati "uživo" i predstavljati svoje rezultate svima koji se registriraju za taj skup, ali i onima koji to mogu da prate kao neku fudbalsku utakmicu, ili koncert, odnosno kao neku vrstu "naučne TV uživo". Naravno, većina naučnih aktivnosti će se odvijati u specifičnom okruženju koje će sve više postajati mjesto okupljanja, umjesto radnih mjesta u tradicionalnom smislu. Upravo to će biti ostvarenje ideje 'Scholarly Commons', gdje će i ljudska bića i mašine umjetne inteligencije zajedno raditi na unapređenju globalnog društva i u korist svih članova akademsko-istraživačke zajednice.

Prevazići će se jezičke barijere, jer će programi kao što je IBM Watson, kompjuterski sistem koji ne samo može da odgovara na pitanja koja se postavljaju u naprednom prirodnom jeziku (QA) nego i da procesuira pohranjene informacije, predstavljanje znanja i automatskog razmišljanja te druge vrste informatičko-mašinskih tehnologija u oblasti otvorenog odgovaranja na razna pitanja iz datog domena. Richard 
i Daniel Susskind pisali su o tome u svojoj knjizi The Future of the Professions: How Technology Will Transform the Work of Human Experts (2016) - da će roboti postati učitelji, ljekari, knjigovođe, arhitekte, pravnici, pa i svećenici, ili bilo koje zanimanje koje se podvodi pod 'bijele' ili 'platinaste' okovratnike, dakle, visoko obrazovane osobe. Oni su pokušali da objasne kako će ti 'sistemi velikog kapaciteta' - od prisutnosti na daljinu do vještačke inteligencije - donijeti krupne promjene u pogledu uloge koju ima praktično znanje (practical expertise) budućih stručnjaka u korist društva u cjelini.

Treba li se plašiti takve budućnosti, u kojoj će akademska profesija izgubiti dobar dio tradicionalno shvaćenog poštovanja, uključujući akademske i druge počasti i nagrade, privilegije, status i ulogu među vodećim ličnostima savremenog svijeta, u natjecanju sa sofisticiranim spravama, koje mogu obavljati ograničeni vid umjetne inteligencije, ali ... u budućnosti koja tek treba da se dogodi, možda budu zamijenjeni robotima ili digitaliziranim spravicama koje mogu ne samo da pohranjuju, proce- suiraju ili diseminiraju ogroman broj metapodataka nego da i sami dolaze do otkrića koja su sada nepojamna čak i najboljim ljudskim mozgovima.

A imajte na umu da uz sav taj tehnički tehnološki napredak, mi i dalje koristimo samo $10 \%$ našeg mozga (preostalih 90\% 'sive mase' koja okružuje centre naših kognitivnih, emotivnih, a i drugih funkcija služi da opslužuje, hrani ili njeguje, te osigura npr. fiziološku funkcije) - jer je takav postotak imao i naš daleki prahistorijski predak, što se nije promijenilo tokom milenija evolucije. Ako bismo u daljem procesu evolucije povećali taj postotak na 12 ili $13 \%$, to bi dovelo i do produženja životne dobi - od 70-80 godina u prosjeku danas do 130 ili više godina života. Jeste li, doista, sigurni da želite živjeti i raditi u takvoj vrsti budućnosti?

Uzevši u obzir moje godine, siguran sam da to neću dočekati. Međutim, neki budući naučnici (ili roboti!) možda nekad konsultiraju ova moja predviđanja i uključe ih u listu zastarjelih referenci iz primitivnog doba ranog 21. stoljeća.

\section{Literatura}

- Bailey, Charles W. Jr. 2010. Transforming Scholarly Publishing through Open Access: A Bibliography. Houston, TX: Digital Scholarship.

- Beall, Jeffrey. 2015. Criteria for Determining Predatory Open-Access Publishers. https://scholarlyoa. com/publishers/.

- Bernes-Lee, Tim, i Fischetti, Mark. 2000. Weaving the Web: The Original Design and the Ultimate Destiny the Worl Wide Web. New York: Harper-Collins Publishers.

- Bosman, Jeroen, i Bianca Kramer. 2016. Views on innovation: The scholarly communication landscape and changing research workflows. Portland, US: Force, 2016. https://figshare.com/account/articles/3185293.

- Brown, David J. 2010. "Repositories and journals: are they in conflict?" Aslib Proceedings 62(2): 112-143. http://dx.doi. org/10.1108/00012531011034955.

- Davenport, T. H. 2005. Thinking for a living: how to get better performance and results from knowledge workers. Boston: Harvard Business School Publishing.

- Drucker, P. F. 1959. The Landmarks of Tomorrow. New York: Harper and Row.

- Drucker. P. F. 1999. Management Challenges for the 21st Century. New York: Harper Collins.

- Ellore, Sushma Bagavadi, Niranjan, Suman, i Brown, Ulysses J. III. 2014. "The Influence of

Internet Usage on Academic Performance and Faceto-Face Communication" Journal of Psychology and Behavioral Science 2(2): 163-186.

- Floris Cohen, H. 2010. How Modern Science Came Into the World: Four Civilizations, One 17th-Century Breakthrough. Amsterdam: Amsterdam University Press.

- Hall, Gary. 2008. Digitize this Book: The Politics of New Media, or Why We Need Open Access Now. Minneapolis - London: University of Minnesota Press.

- Harvard. 2007. Writing with Internet Sources: A Guide for Harvard Students. Cambridge: President and Fellows of Harvard College. www.fas.harvard. edu/ expos.

- FER. 2012. Hrvatska deklaracija o otvorenom pristupu. https://www.fer.unizg.hr/oa2012/deklaracija.

- James, Carrie, Katie Davis, Andrea Flores, Francis, John M., Lindsay Pettingill, Margaret Rundle, i Gardner, Howard. 2009. Young People, Ethics, and the New Digital Media: A Synthesis from the GoodPlay Project. Cambridge, MA: MIT Press.

- McGreal, Rory, Wanjira Kinuthia, i Marshall, Stewart, ur. 2013. Open Educational Resources: Innovation, Research and Practice. Vancouver: Commonwealth of Learning and Athabasca University.

- OECD. 2015. OECD Frascati Manual 2015: Guidelines for Collecting and Reporting Data on Research and Experimental Development, The Measurement 
of Scientific, Technological and Innovation Activities. Paris: OECD Publishing.

- $\quad$ Petrak, Jelka. 2014. Otvoreni pristup - put k znanju kao javnom dobru. http://medlib.mef.hr/2224/1/ petrak_j_rep_2224.pdf.

- Ramsey, Colin, i Martha McCaughey. 2012. "Copyright for Academics in the Digital Age": 10-17. http://www.aaup.org/article/copyright-academicsdigital-age\#.VDVu5haZfLc.

- $\quad$ Read, John. 1957. From Alchemy to Chemistry. London: G. Bell.

- Rittman, Martyn, ur. 2018. The Global Benefits of Open Research. Basel - Beijing - Wuhan - Barcelona - Belgrade: MDPI.

- $\quad$ Susskind, Richard i Daniel. 2016. The Future of the Professions: How Technology Will Transform the Work of Human Experts. London: Oxford University Press.

- UNESCO. 2015. Concept of Openness and Open Access: Module 2. Paris: UNESCO.

- The Economist. 2015. "The world is going to university" The Economist. March 28, 2015. http://www. economist.com/news/leaders/21647285-more-andmore-money-being-spent-higher-education-toolittle-known-about-whether-it.
- Weller, Martin. 2014. The Battle for Open: How openness won and why it doesn't feel like a victory. London: The Ubiquity Press.

- Willinsky, John. 2006. The access principle: the case for open access to research and scholarship. Cambridge, MA: MIT Press.

- Willis, Martin. 2013. Slow Science: A short commentary and opinion piece on a new movement in scientific practice. https://www.academia.edu/2352732/ Slow_Science.

- White, Robin C. A. 2009. Writing Guide 2: Writing a Research Paper. School of Law. Leicester: The University of Leicester. http://www2.le.ac.uk/.

\section{Internetski izvori}

- $\quad$ http://blogs.lse.ac.uk/impactofsocialscien ces/2015/11/11/101-innovations-in-scholarly-communication/

- http://blogs.1se.ac.uk/impactofsocialsciences/files/2015/11/author-tools-3.png

- http://www.manuscriptsapp.com/

- http://www.sherpa.ac.uk/romeo/

- http://www.webometrics.info/en/node/54

\title{
FOR AND AGAINST OPEN ACCESS TO ACADEMIC WORKS IN THE CONTEXT OF CONTEMPORARY RESEARCH AND PUBLISHING PROCESS
}

\begin{abstract}
Ever since the accelerated introduction of information technologies and Internet services there have been many initiatives to, under certain conditions, make all the published, printed and digital, works fully accessible to all the people, and, especially, to members of research and academic/scientific community all over the world. Principles of Open Access Policy gained many supporters in the last twenty years, but, also, a number of opponents, who, within reason, point out to abuses by so-called predatory academic publishers and everpresent commercial aspects within the frameworks of binding legal and other documents both at the local and international levels that have not been yet agreed upon. The paper presents a short historical review about the development of academic publishing from 17th to late 20th century, and a significantly changed current environment that tries to overcome numerous legal and other types of dilemmas related to research and interrelated publishing activities. It is highly dynamic process that caused many changes in terms of approach and evaluation of academic writing; whereas the issues of authorship and publishing rights have been re-defined. Different kinds and modes of (self-)archiving and publishing of final types of academic publications, as well as their subsequent dissemination to interested users without limitations have been duly explained. Certain advantages under the open access policy have been pointed out, but also some negative aspects that such initiatives are about to be faced with in a near future, until the agreement on standards in this area will have been reached in the course of 21st century that might attain a comprehensive regulations on the global level.
\end{abstract}

Keywords: open access, supporters and opponents, authorship, types of archiving, publishing, dissemination and use of academic and scientific works without restrictions, the future of academic publishing in the digital environment of 21 st century 